\title{
LIMITS OF THE ALMIGHTY: MEHMED II'S 'LAND REFORM' REVISITED
}

$\mathrm{BY}$

\author{
OKTAY ÖZEL*
}

(Bilkent University, Ankara, Turkey)

\begin{abstract}
This paper reviews the reform attempt that took place in the Ottoman Empire during the last years of Mehmed II (1451-81), which is generally referred to as a "land reform" in Ottoman historiography. First, it emphasizes that the freeholds, the main target of the said reform, were 'revenue-holdings' not land-holdings. Second, based on the examination of a tax register belonging to the Anatolian province of Amasya, it shows that the reform brought no fundamental change in the existing revenue holding system, let alone in the land relations, which remained entirely outside the scope of the reform. Finally, the article describes Mehmed II's attempt, insofar as reflected in north-central Anatolia, as no more than a somewhat superficial "fiscal" reform, which eventually resulted in failure upon his death, revealing the vulnerability of the positions of the sultans in their struggle for power against the centrifugal forces in the Ottoman Empire.
\end{abstract}

\section{Introduction}

Speaking of Mehmed II's last Grand Vizier, Karamani Mehmed Pasha, in his fifteenth century-chronicle History of the House of Osman, Aş1kpaşazade pours out his anger:

Wherever there are wrongs and injustice they are his [Mehmed Pasha] creation. He has abolished all vaklfs and mülks that were established in Ottoman lands according to the sharia of Muhammed and seized their revenues for the treasury of the sultan. When asked, he replied "they were not valid, [so they are now] abolished" (...) Once I went to him and asked: "These mülks and vakıfs were established in accordance with the sharia of Prophet Muhammed (....) How can you abolish them?" He said: "Why do you ask me such a question. Were any of your possessions also abolished?" (...) When he died, he was buried without his head [on his shoulders]. ${ }^{1}$ )

*) The author would like to thank his colleagues Mehmet Öz and Fatma Acun of Hacettepe University, and York Norman of Bilkent University, for their comments and valuable suggestions on the first draft of this study.

1) Aşıkpaşaoğlu 1949, pp. 244-45.

(C) Koninklijke Brill NV, Leiden, 1999

JESHO 42,2 
The event to which Aşıkpaşazade refers in this passage was in fact the socalled 'land reform' of Mehmed II, the Conqueror, that was carried out in the Ottoman Empire in the last years of his reign, in the late 1470s. Mehmed Pasha was known to have been the mastermind and principle initiator of this reform, in his capacity first as chancellor (nişancl), and then as Grand Vizier of the time. It seems that Aşıkpaşazade's sentiments and reaction to this reform attempt, as well as to the person behind it, were not personal; there was widespread discontent among the ulema, as well as Sufi orders, dervishes and a large number of individuals and families directly targeted by the attempt. Among the latter were members of the local aristocracy, which was especially powerful in Anatolia, and those enjoying the privileges of having freehold possessions, mülks and vakufs, throughout the empire.

Narrative sources mention that, in the course of this reform, the revenues of some twenty thousand villages and farms, which had previously been held as freehold by these individuals or allocated to pious foundations or various dervish convents as vaklfs, were converted into state ownership within the mirî system. ${ }^{2}$ ) Archival materials reveal that some of the previous owners of such freeholds were made into state functionaries as timariots; in other cases the state imposed the obligation to serve personally in the sultan's army or send an armed man (eşküncü). Others, however, seem to have lost all their possessions; the confiscated holdings were later distributed by the Sultan as timars to the soldiery in order to expand the provincial cavalry army. ${ }^{3}$ )

A series of tax registers from the early years of the reign of his successor, Bayezid II, shows that this ambitious empire-wide reform of Mehmed II did not endure long after his death in 1481; in the first months of his rule, the new sultan ordered the restitution of mülks and vaklfs by issuing documents confirming their freehold status. ${ }^{4}$ ) Narrative sources however do not say much about the reason(s) behind this decisive act of Bayezid II, just as they remain silent on the causes of his father's radical reform attempt.

The subject has attracted a certain degree of attention in Ottoman historiography and been the focus of a few studies since the 1960s. It was first referred to in the 1930s and 1940s in Ö.L. Barkan's early works on the Ottoman land system and various aspects of freeholds in the Ottoman Empire. ${ }^{5}$ ) In these publications, Barkan approached mülk and vaklf-holdings mainly as 'land' possession

2) Tursun Bey 1977, pp. 22, 197; Compare İnalcık 1957, p. 533.

3) İnalc1k 1994, p. 127.

4) For certain records contained in such registers see Barkan 1942, pp. 279-386; Gökbilgin 1952.

5) Barkan 1942; 1980a; 1980b; 1980c. 
or 'land-holding'; in this context he referred to Mehmed II's attempt to abolish these holdings in order to convert them into state-property, i.e. mirî. His treatment of these freeholds as 'land'-holdings was shared by later historians and reiterated until today. In his article published in 1957, Halil İnalc1k referred to Mehmed II's attempt as 'land reform'. $\left.{ }^{6}\right)$ Since then, this approach has received general acceptance from Ottomanists. Among them was B. Cvetkova, who dealt with the issue separately in an article published in 1963, and re-formulated these freeholds under the category of 'land estates' and the owners as 'landowners'.7) Accordingly, she treated Mehmed II's attempt again as a 'land reform' aimed at strengthening Ottoman military organisation to the detriment of this land-owning aristocracy, which represented decentralising tendencies in the Ottoman feudal system. Two years later, N. Beldiceanu took up the issue, concentrating particularly on the possible date of the beginning of the reform and its possible causes. ${ }^{8}$ ) He suggested the year 1476 as the beginning of the reform. As for the causes, he pointed mainly to the financial and military needs of the Ottoman government as primary causes, and drew attention to the possibility that Mehmed II and Karamani Mehmed Pasha might have thought not only of financial profit but also of weakening the economic power of the dervish orders, whose influence, through the many vaklf-holdings they held, was becoming embarrassing for the state. Beldiceanu also noted the possibility that the jurists of the time of Mehmed II might have influenced the Sultan to return to the purist form of Islamic Law, by abolishing vaklf and mülks which were considered by some as being against Sharia. Vera Moutafchieva's work on agrarian relations in the Ottoman Empire, which was published in English in 1988, furthered the discussion on the issue with particular reference to various aspects of mülk and vakıf types of 'land ownership' and their role in the foundation of a 'feudal land-owning aristocracy' in the empire. She then depicted the attempt of Mehmed II as a radical reform against mülk and vaklf land ownership. ${ }^{9}$ )

It appears that the general approach to freeholds in the Ottoman Empire and the main arguments developed in the above-mentioned studies of Mehmed II's reform received general acceptance and were frequently referred to uncritically in Ottoman studies. ${ }^{10}$ ) The main point in their approach is that they all see mülks

6) İnalcık 1957; Compare İnalckk 1970, p. 304; idem. 1991, p. 980.

7) Cvetkova 1963.

8) Beldiceanu 1965

9) Moutafchieva 1988, pp. 61-138; particularly pp. 131-137. An earlier version of this book, however, seems to have been published in Sofia as early as 1962 (see Beldiceanu 1965, p. 27 , note 3 ).

10) See for instance, Sertoğlu 1970, pp. 68-71; Vatin 1989, p. 104; Beldiceanu 1980, p. 46. 
and vaklfs as 'land' possessions or land-holdings in essence, not 'revenue'holdings. ${ }^{11}$ ) However, a few historians have treated the phenomenon much more carefully, emphasising the fact that these freeholds in the Ottoman Empire should be treated as revenue-holdings, not land-holdings. ${ }^{12}$ ) Despite the significant contribution of these works in outlining the issue, certain aspects of Mehmed II's reform attempt are still far from having been clarified. Among them, perhaps the most important is the very name of 'land reform', by which the attempt is generally referred to. It seems that the term 'land reform' not only poses certain problems in itself in the historical perspective, but it may also be misleading in understanding the real nature of the reform attempt of Mehmed II. To understand this, one should first look at the land relations that existed in the empire, and various aspects of the relations of production and of proprietorship in particular. Once this has been clarified, we can ask what actually the main target of the reform was, the land or the tax revenue derived from it? Only then, by examining the process of the reform on the spot, can we look at whether the reform brought about any change in the ownership of the land wherever it was implemented, and if so, to what degree. Did any change in this regard also mean a change in the position of the peasantry as a direct producer, or in their relations with the land? Another important question is whether, during the reform, the Ottoman government did pursue different policies towards mülkand vaklf-owners in the Balkans and 'malikane'-holders of Anatolia. In this respect, did the reform aim at the final elimination of the local aristocracy, which was particularly powerful in Anatolia where there existed a different revenueholding system, i.e. the malikane-divani. For instance, did the Ottoman administration attempt to sever all their relations with the land or with the revenue that had been assigned to them by previous Muslim rulers? This is another important point to be borne in mind particularly when assessing its political dimension.

The published research mentioned above does not seem to have paid enough attention to such points in dealing with the subject, thus leaving many aspects in obscurity. The so-called 'land reform' of Mehmed II therefore still remains in historiography a subject which requires further examination. This is what this study aims to do to a certain degree, by questioning some of these aspects, with

11) This is clearly seen in the terms "mülk-land", "vakıf-land", or "land-mülks", "landvaklfs", or "land-malikanes" they frequently use in their works. Halil İnalc1k, who seems to have been the first historian to refer to Mehmed II's reform as a 'land reform', appears in his later works to have avoided calling it so; he, however, still uses the above mentioned terminology in his latest work, thus treating the mülk and vakıf as 'land possessions' (see İnalcık 1994, pp. 120-129).

12) Venzke 1986 , p. 452 ; Kunt 1988 , pp. 86-87. 
special reference to the reflections of the reform in the North Central Anatolian district of Amasya. Having done so, we will be in a better position to assess some other important aspects of this reform attempt and its socio-political implications, upon which the Ottoman sources generally remain silent; it appears that these implications can only be analysed within the wider framework of the power relations in the Ottoman Empire. When viewed in this context, the reform attempt of Mehmed II in the last quarter of the fifteenth century may be considered to constitute only a small but an extremely revealing episode of the struggle for power which seems to have always manifested itself in the Ottoman Empire in different forms at different times.

\section{Mülks and Vakıfs: Land-holding or Revenue-holding?}

Before moving to a closer examination of Mehmed II's reform, let us recall the general outline of the Ottoman financial system, which will provide us with a necessary framework to fit the reform within the organisational structure of the state. It will also give us an idea at the outset of the main principles upon which the Ottomans organised land relations, thus helping us in discussing the true nature of the reform. It is well-known that the Ottoman financial administration was based on the assumption that the ultimate right of ownership (rak$a b a$ ) of land belonged to the state. ${ }^{13}$ ) The land in this system was tilled by the peasantry (reaya), who held the usufruct right (tasarruf); they were engaged mainly in agriculture, producing the main economic wealth in the empire within small peasant family units, generally known as çift-hane. ${ }^{14}$ ) In Inalcık's words, "having inalienable sovereign rights over the reaya, ${ }^{15}$ ) the state claimed the right to peasants' surplus production as tax or rent. The taxes were either collected directly by the state treasury or allocated by the state to fief-holders within the timar system. In this system, the state handed over the right to collect certain parts of the tax revenue from arable lands of certain localities to members of its provincial cavalry army as living (dirlik) in return for their service to the state. ${ }^{16}$ ) The dirlik-holder (regardless of whether he was a timariot, i.e. sipahi, 30

13) For the discussions on the issue see Barkan 1980a, pp. 125-149; İnalcik 1992, pp. 15-

14) This term was first suggested by Halil İnalckk and recently has received general acceptance by Ottomanists. See İnalcık 1993, pp. 137-160. Compare İnalcık 1994, pp. 143-153.

15) İnalcık 1994, p. 128.

16) It is known, however, that such dirliks were sometimes given to non-military individuals, who undertook in one way or another certain public services; but they were marginal on the whole, both in number and in the amount of revenue that accrued to them (see Beldiceanu 1980, pp. 38-45). 
or a zaim, or a high-ranking dignitary holding has) did not own the land itself; nor did he have any ownership right over the peasants cultivating the land in his holding. He was simply a revenue-holder with no immunities, and the duration of his holding depended on his loyalty to the state; failure in his service could easily result in the withdrawal of his dirlik, which would be given to another dignitary. This system provided the Ottoman central authority with the power to control both arable land and the peasantry. Throughout its classical period, the Ottoman administration made great efforts to establish this revenueholding system firmly in the core lands of the empire, i.e. Anatolia and Rumelia, and develop the empire's fiscal structure on this basis. ${ }^{17}$ )

There were other forms of revenue-holding in the Ottoman Empire as well. Though they often tended to be seen by scholars as 'exceptional', they were in fact as old a practice as state ownership in the Islamic world. Like all previous Muslim rulers, the Ottoman sultans followed the ancient tradition of giving revenue grants to individuals, usually to military leaders, as a reward for their great zeal and courage during conquests, or to some sheikhs and dervishes as part of the state's settlement process in newly conquered territories. The revenues were granted as freehold, i.e. mülk, with large immunities such as the right to sell, donate, mortgage, and leave it to their heirs. ${ }^{18}$ ) However, it appears that these immunities did not include the right of ownership of the land itself. ${ }^{19}$ ) Most of these mülk-owners, in time, turned their mülks into pious endowments, i.e. vaklfs, through which the revenues were either kept within the family of the owners for generation $\mathrm{s}^{20}$ ) or channeled into various public services. Besides this, we see another type of free-holding system that the Ottomans had inherited from the previous Muslim states in Anatolia and certain Arab provinces: the malikane-divani. ${ }^{21}$ ) In this regime, the members of the local aristocracy held hereditary rights over certain taxes known as malikane, while the state also held claim to its share of taxes under the name divani. This was a system of dual ownership of agricultural revenue; for the peasantry, it meant heavier exploitation. ${ }^{22}$ ) It is not clear, however, whether malikane-holders held the ultimate

17) For further information on the timar system, see Inalc1k 1973, pp. 104-118.

18) For freehold system in general in the Ottoman empire and the mülk and vakuf type revenue-holdings in particular, see Barkan 1980b, 1980c; Moutafchieva 1988, pp. 61-138; İnalc1k 1994, pp. 120-126.

19) Barkan 1980c, p. 253.

20) This was a common practice throughout the empire and carried out through family waqfs or evlatllk vakıfs (see Barkan 1980e).

21) For the malikane-divani system, see Barkan 1980d; Beldiceanu-Steinherr 1976, pp. 241-277; Venzke 1986; Öz 1994. Compare İnalc1k 1994, pp. 126-130.

22) They simply paid double tithe, one for malikane-owner and another for the divaniholder, who was usually a timariot. 
ownership of the land in this system; there is no agreement on the issue in historiography. ${ }^{23}$ ) Even if they were the owners of the land in legal terms as claimed by Barkan, in Ottoman practice, it is obvious that they were no more than hereditary revenue-holders with the same rights as mülk-owners. ${ }^{24}$ )

As for land relations, for most of its history the state was the only legitimate power to organise land and labor in the Ottoman Empire. The main principles of relations of production in particular were gradually developed by the state within the çift-hane system in the mirî land regime; its legal framework was introduced as a mixture of the Ottoman interpretation of basic Islamic principles on the one hand, and the existing local practices found in newly conquered lands on the other. Based on the assumption of state-ownership of the land, in this system, the position of the peasantry and their relations with the land in the production process in particular, were determined and organised exclusively by the state. ${ }^{25}$ )

The situation was no different in the freehold system. As mentioned earlier, neither a mülk- nor a malikane-owner had any right to interfere in the above mentioned relations in his holding; at best, implicit in his being a revenueholder, the owner had limited conditional rights to oversee the peasants in his holding, in their fulfillment of the obligations imposed by the state. This was particularly so for the owner of a mülk or a vaklf in the 'free' estate category, i.e. serbest mülk. ${ }^{26}$ ) The same was true for the vaklf holdings. In spite of the theoretical ambiguity as to whether the malikane-holder or the state held the ownership right (rakaba) over the land in the malikane-divani system, in all types of freeholdings, including vaklfs, the state appears to have always withheld the exclusive right to control the land and the peasantry, and maintained

23) Some historians are of the opinion that the malikane-owner held the ownership right (rakaba) to the land in this system (Barkan 1980d, p. 154; Sertoğlu 1970, p. 71), whereas according to some others it was the state who held the rakaba (Beldiceanu-Steinherr 1976, pp. 296-300; Beldiceanu 1980, p. 33).

24) Their rights, however, did not include any fiscal and administrative immunities that the owners of mülks and vaklfs with 'free' status had in their holdings (see Barkan 1980d, pp. 119-124; Venzke 1986, pp. 453-54).

25) A series of general and provincial law codes (kanunnames) prepared by the Ottoman imperial registry regularised such relations in areas where mirî land system was applied. See İnalcık 1975; Barkan 1945.

26) Moutafchieva 1988, p. 105; İnalckk 1994, p. 122. Peasants were registered exclusively in the name of the revenue holder in typical mülk- and vaklf-holdings; therefore, the freeholder or the administrator of the vakuf acted in the capacity of a dirlik-holder, and exercised the power as such, thus undertaking the responsibility to oversee the peasants' obligations in his holding. In the malikane-divani system, on the other hand, this was only the divaniholders' responsibility, except in the cases where divani and malikane shares were held by the same person. See Barkan 1980c, p. 253. 
its right to interfere in matters of proprietorship and the organisation of agricultural production. ${ }^{27}$ ) Even at the level of the appropriation of the surplus in the form of tax or rent, it was again the state who imposed the regulations and dictated the methods of revenue extraction by the freeholder in his holding. ${ }^{28}$ ) In short, in the Ottoman Empire under the period in question the proprietory right of freeholders as a whole never exceeded the right of ownership of the revenues, initially assigned to them by the sultan, who represented the state authority. Their rights over the revenues assigned, however, were recognised by Islamic Law, as full private ownership, and sanctioned as such. ${ }^{29}$ ) What this meant was that no Muslim ruler could ever abolish freehold status of these holdings.

As will be seen below, this is exactly what Mehmed II attempted to do in his reform. There is evidence showing that he had already given orders, from 1459 onwards, for the inspection of the arable lands within the timar system; the aim was to search for plots of lands without owners and, if any, include them in land registers as a new source of revenue to be granted to timariots. ${ }^{30}$ ) In the following years, it appears that he extended the scope of his fiscal policy of creating new revenue sources for the central treasury: from 1472 on, we see imperial edicts ordering the transformation of certain mülks and vaklfs in various parts of the empire into state property. ${ }^{31}$ ) However, we do not have clear evidence of when exactly Mehmed II ordered an all-out reform that directly targeted mülks and vaklfs throughout the empire. N. Beldiceanu holds that the year 1476 was a turning point in this respect; according to him, after returning from the campaign against Moldavia in late 1476, Mehmed II ordered a general census of timars to update the registers. This done, he must have proceded

27) Barkan 1980c, pp. 257-58; İnalcık 1994, pp. 124, 125. The only exception to this, however, is the fact that the owner of a mülk or a vaklf could employ slaves, however acquired, in agricultural production in his holding outside the status of normal raiyyet (i.e. legally recognized peasant), and exploit them in ways he considered fit. This practice, which was not uncommon, was carried out entirely beyond state control (Moutafchieva 1988, pp. 112-113). As İnalcik points out, however, such differences disappeared, either as a result of the intervention of the state or the abolishment of the slave status of these peasants by the holders themselves, over time, and the land and labor organisation in mülk and vaklf holdings began to take the regular form of a family labor farm or çift-hane. Once normal reaya status of peasants was established within çift-hane system in such holdings, the freeholders could not alter it (İnalcık 1994, pp. 125, 126).

28) See Moutafchieva 1988, pp. 104-105; 123-128. Compare Barkan 1980c, pp. 256-58.

29) İnalcık 1994, p. 128.

30) Cvetkova 1963, pp. 108-109.

31) Beldiceanu 1965, pp. 32-33. However, Moutafchieva gives an earlier example of the abolishment of a mülk, which, she thinks, must have happened in the years between 146468 (see Moutafchieva 1988, p. 132). 
to abolish mülks and vaklfs empire-wide, as the first step in his reform. He also maintains that the appointment as Grand Vizier in 1478 of Karamani Mehmed Pasha, who had held the position of chancellor (nisancl) since 1464 and was influential in the sultan's undertaking, must correspond to an intensification of the reform, as the sultan was calling on the man who had inspired him. ${ }^{32}$ ) Halil Inalckk, on the other hand, points out that Mehmed II ordered an investigation of all founding charters of mülks and vaklfs for re-validation in 1478; accordingly, freeholds which did not meet the requirements were to be abrogated and re-assigned to the state ownership. ${ }^{33}$ ) But he does not refer to any specific edict for such an order.

As mentioned at the beginning, available sources make no mention of the reasons behind this reform. However, from the analysis of the reign of Mehmed II as a whole, some explanations have been suggested by the historians referred to earlier. According to them the reform was largely necessitated by a) military needs, i.e. the need to increase the number of cavalry soldiers (sipahis), organised on the basis of the timar system, b) financial needs which led the government to search for new revenue sources for the treasury to overcome the great budgetary problems resulting from the successive military campaigns carried out throughout the reign of Mehmed II, and c) the need on the part of the government, pursuing centralist policies under the same Sultan, to diminish both the economic and political power of dervish convents and the local aristocracy, most of whom were in fact holding mülks and vakıfs.

\section{Mehmed II's Reform under Scrutiny: The Case of North-Central Anatolia}

Let us now look at what this reform attempted to do and how it was implemented in some detail. As mentioned above, during the reign of Mehmed II, some attempts were made to determine the taxable sources of the empire, these mainly being arable land and the peasantry. To that purpose, three general surveys (tahrirs) were carried out during his time, first in 1454-55, second in 146465 , and the third after $1476 .{ }^{34}$ ) It seems that the last one was associated with the reform in question. Research done on these surveys shows that only a few of the registers (tahrir defters), which were compiled as a result of this survey, appear to have survived to the present day. One of those registers, the one belonging to the district of Hamit, has been examined by Zeki Arıkan. The reg-

32) Beldiceanu 1965, p. 34

33) İnalckk 1994, p. 126

34) Beldiceanu 1980, p. 79. 
ister, which had no date but was attributed by Arıkan to the years 1475-1481, seems to be an example of a typical detailed register (mufassal defter) in format, but includes at the end a list of the villages whose revenues, previously held as mülk or vaklf, were turned into timar. It also contains occasional records concerning the abolishment of the "mülk" status of some other freeholds in the region. ${ }^{35}$ ) In his work, Arıkan gives some examples of such records, and then notes the restitution of their status as freeholds under Bayezid II, citing the records in the register from the period. What we presently know about the reform of Mehmed II is, in fact, mostly through such records from the time of Bayezid II; they simply refer to the fact that the revenue of a given village or a separate piece of land cultivated by the inhabitants of nearby villages (mezraa), which had originally been held as mülk or vakuf, had been turned into timar by Mehmed II, and presently was ordered by the current sultan (Bayezid II) to be given back to its former holder[s] again as mülk. ${ }^{36}$ )

Given the scarcity of original sources available from the period during which the reform was carried out, the significance of any register with first hand information, like the one belonging to Hamit region, becomes apparent. There exists in the Ottoman archives a similar register (TT15) covering the province of Rum, which appears to have been compiled during the reform years; ${ }^{37}$ ) it therefore contains records directly related to some of the malikane-holdings in areas constituting most parts of north-central and eastern Anatolia. The register offers valuable information about how the reform process started in the region. Before examining certain aspects of the reform in a certain part of the province, one should remember at this point that the Ottoman province of Rum included the territories which had constituted the core lands of the Anatolian Seljukid state from the twelfth to mid-thirteenth centuries; from the ruins of the Seljukid state

35) Arıkan 1988, pp. 7, 122. For a reference to a similar register belonging to the district of Konya, see Barkan 1942, pp. 328-329.

36) A number of such records concerning various parts of the empire have been subjected to examination or published by various scholars. See the works referred to in Note 1 above. Compare Moutafchieva 1988.

37) The register in question is preserved in the Ottoman Archive of the General Directorate of State Archives (formerly 'Prime Ministry Archive') in İstanbul in the section of Tapu Tahrir Defterleri under the number TT15. This is in fact a mixed-icmal or abridged kind of register, which seems to have been prepared in early stages of the reform proccess, most probably between 1476 and 1480 . From the references found in the register, it becomes clear that there had been a detailed (mufassal) register, which must have been compiled just before TT15, but not survived to the present. This missing mufassal may well have been drawn up as a result of the general survey of the region that was undertaken around 1476-77, and was probably similar in content to the one belonging to Hamit district (see Note 35 above). For further detail on TT15, see Özel 1993, Appendix I. 
which had collapsed after the crushing defeat against the invading Mongol armies at the battle of Kösedağ in 1243, there emerged in the area local emirates either under certain military leaders or under the chiefs of Turcoman tribes. Having established petty local dynasties in their respective emirates, they were in constant war against each other, to expand their authority over neighbouring territories. ${ }^{38}$ ) When the Ottomans annexed these areas, from the last decade of the fourteenth century onward, they found the revenue-holding system of the malikane-divani type already in existence, and it seems that they recognized, as part of the reconciliatory policy they adopted, the hereditary malikaneholdings held either as mülk or vaklf by hundreds of members of the local aristocracy. The register in question therefore is of particular importance in examining the nature and the extent of Mehmed II's reform in regions where the malikanedivani system was in force. In the following are certain remarks on the situation as reflected by the register not in the whole province of Rum, but only in an area limited to the district ( $k a z a)$ of Amasya.

Looking at the format of the register, it becomes clear that this was an abridged register with references almost exclusively to a detailed (mufassal) register of the same region. It initially aims to gather information about the dirlikholders and their holdings in the province of Rum, along with records relating to the situation of certain mülk-and vaklf-holders as well as the lists of some malikane revenues. It is understood from this format that the register does not provide a complete description of the situation relating to all freeholds in the region, thus giving a rather limited picture. However, on the basis of these records, certain observations on the reform process in the region can be made.

First of all, the register gives a list of mülk- and vakuf-holders who held certain parts of the malikane revenues of certain villages and mezraas, and states that these freeholders were made into timariots with the obligation either of serving personally in the army or sending armed-men, the number of which varied according to the size of their holdings. The heading of the list ${ }^{39}$ ) here refers to the status of "eşküncülü mülk" or "mülk timar", examples of which were not uncommon in the Ottoman Empire. ${ }^{40}$ ) It is well known that the main principles of both mülk and timar systems were merged in this particular type

38) For a general view of this period in Anatolia in general, see Turan 1970. The violent nature of these struggles is best illustrated by the account of Aziz bin Ardashir (d. after 1398), a panegyric history of Kadı Burhanüddin Ahmed, the Emir of the principality bearing his own name. See Esterabadi 1990.

39) "Those who are required to serve in the army while keeping their mülks" ("eşkünciyân ki mülklerinde eşerler", see TT15, p. 77).

40) Barkan 1980f 
of freehold, the origins of which date back to pre-Ottoman times; as in the case of malikane-divani system, the Ottomans seem to have maintained this practice to a certain extent in areas where a strong local nobility existed. However, they always showed a tendency to abolish such a practice, whenever suitable, by simply turning the 'eşküncülü mülk-holder' into an ordinary timariot. ${ }^{41}$ ) Given the peculiarity of the area in question, the district of Amasya, with its strong malikane-holding local aristocracy, one tends to think that the mülk timars which were listed in the register under the category of "eşküncü" must have been those that had originated from the pre-Ottoman times, and the Ottomans had always recorded them as such in the previous registers. ${ }^{42}$ ) But, a closer examination of the records reveals this was not so; on the contrary, they had been typical malikane-holdings, hereditarily held by certain noble families either as mülk or vakuf up until the compilation of the register in question. The records clearly show that they were turned into 'mülk timar' with the obligation of eşküncü at the time of the compilation of the register, ${ }^{43}$ ) which must have taken place after the 1476 survey; we should remember that this survey aimed at updating the state records with the special purpose of increasing sources of income for the treasury. In the list, we find only one case in which the preOttoman origin of the 'eşküncülü mülk' status is referred to. ${ }^{44}$ )

These records suggest that in the district of Amasya, 46 mülk timars listed in the register as "eşküncü" were in fact created after the 1476 general survey and recorded accordingly in the register in question. Holders of these timars, whose number amounted to some 75 persons including females, retained their mülk- or vaklf-holdings, which were composed of certain shares of the malikane revenues of some 85 villages and 3 mezraas, either as mülk or vakuf with the status of "eşküncü".

There is another list in the register, this time concerning the breakdown of certain shares of the malikane revenues of some 18 villages and 3 mezraas, which had previously been converted into mirî. ${ }^{45}$ ) These malikane revenues were recorded in the register as "mevkufat", showing that they had not yet been allocated by the state to timariots; in other words they were malikane revenues in

41) Barkan 1980f, pp. 901-902.

42) However, no previous register of the region has survived to the present.

43) "Mülk deyu tasarruf iderler imis. Tasarruf-ı kadimleri üzere mutasarrıf olub sefer-i zaferpeykâra eşeler" (TT15, p. 77); "emr-i âli mucebince eşmek emrolundu" (TT15, p. 79); "şimdikihalde hissesince eşe” (TT15, p. 78). Compare Barkan 1980d, p. 187.

44) "Kadimden eşküncülü mülk imiş (. . .) ber karar-l sabık eşeler", (TT15, p. 86).

45) "Mevkufat which had previously been turned [to mirîl]" ("mevkufat ki sabıka döndürülmüşdü”, see TT15, pp. 245-251). 
the state's reserve during the time of the compilation of the register. ${ }^{46}$ ) On the other hand, the revenues of three other villages were ordered to be given as timar to a prominent figure of the region, Mehmed Beğ son of Hizır Paşa. ${ }^{47}$ ) What these records reveal is that the Ottoman registry office had earlier turned some malikane revenues, which had presumably been newly-discovered and vacant, into state property, but these revenues had not yet been distributed among its functionaries within the timar system by the time this register was drawn up. It is not possible for us to know whether this was done at a later stage of the reform. However, the testimony of other state records from around 1520, points to a different picture, according to which at this date most of these revenues constituted the mülk-and vaklf-holdings of various families. ${ }^{48}$ )

The register contains a third list which gives the malikane revenues of a further 86 villages and 13 mezraas; from the heading of the list, it is understood that the state of affairs of these malikane revenues was not mentioned in the mufassal register, which is referred to as the main source of information given in $T T 15 .^{49}$ ) It seems that the surveyors were not able to clarify the position of these malikane revenues during the 1476 survey, and recorded them in the mufassal as having no holders when TT15 was prepared on the basis of this mufassal, the scribes simply noted the situation. But, as in the mevkufat category mentioned above, in the 1520 s, we see an overwhelming majority of these revenues having been identified again as components of various mülk- or vakıfholdings..$^{50}$ )

As seen from this picture presented by TT15, in the early stages of the reform years the Ottoman government does not seem to have taken any radical steps in doing away with mülks and vakıfs in the district of Amasya, such as categorically abolishing or abrogating them. Nor did it even attempt to systematically convert into state property the malikane revenues held by freeholders in one way or another. What, it seems, the Ottoman administration did in this particular region was in fact no more than bringing the malikane revenues, the

46) It is known however that until they were re-distributed as timar, such revenues were collected for the treasury by a state agent called mevkufcl (for an example, see Barkan 1942, p. 313, document no. 33, "sonra mensuh oldugile mevkufcr tasarruf eylemis").

47) "Mevkufat which were ordered to be given as timar" ("mevkufat ki timara emrolundu", see TT15, pp. 250-51).

48) See the related records in TT387. For a recent study on this register Murphey 1995-96.

49) "Malikanes of the province of Rum whose state of affairs are not mentioned in the [mufassal] register" ("mâlikâne-i vilâyet-i Rum ki keyfiyetleri defterde mezkûr deḡill", see TT15, p. 221).

50) See the related records in TT387. 
owners of which the surveyors had not been able to identify, under state property and recording them as such in order to later distribute them to timariots. To this end, one might suggest that these revenues, which the state considered vacant at the time of registration, were the only ones that were created during the survey as a 'new source of revenue' for the central treasury. However, it appears that around 1520 most of the malikane shares which formed this 'new' revenue source constituted parts of various mülks and vaklfs, not parts of the holdings of timariots. This can be accounted for by the possibility that these malikane revenues in fact had owners, whom the surveyors, for one reason or another, had not been able to identify during the survey and registration, and that these owners turned up in the later years of the reform with the documents proving their rights over these revenues, thus restituting their holdings. ${ }^{51}$ )

In discussing the reform of Mehmed II in the region under examination, it must be pointed out that many timar-holders in late fifteenth century Amasya were in fact members of the local nobility, and that their holdings included, sometimes exclusively, malikane revenues. ${ }^{52}$ ) Some records concerning such holdings also reveal interesting changes that seem to relate to the reform of Mehmed II. To give an example, among the timar-holders in TT15 was a certain Barak Beğ son of Mirza, who had an unusually large timar, some of which derived from malikane revenues of a group of villages in the district of Amasya. ${ }^{53}$ ) In the sixteenth century registers we find these malikane revenues belonging to his sons, Mahmud Çelebi and Yakubşah Çelebi, as vakf-ı evlad or family waqf. ${ }^{54}$ ) In a register of day-to-day changes in timar-holdings of the empire which contains records from 903/1493 on, we find a record concerning a timar allocation to the former, Mahmud, who was registered as "serasker", or military commander of Amasya. ${ }^{55}$ ) From the same register we also find out that Barak Beğ had a third son, called Ahmed, who was then (1490s) the treasurer dealing with timar affairs (timar defterdart) of the province of Rum. ${ }^{56}$ )

From this state of affairs, it seems that Barak Beğ was a prominent figure in the region in the 1470s and had previously held at least the malikane part of a

51) Compare İnalckk 1947, pp. 702-703, document no. 14.

52) See TT15, pp. 37-74.

53) $T T 15$, p. 43.

54) TT387, p. 358 . For the situation in 1576 see, TK26, pp. 116b-117a, 117b-118a, 120b121a, 134b-135a, 156a-157a. TK26 is the first volume of the mufassal register of the district of Amasya which is preserved in Kuyud-ı Kadime archive of General Directorate of Deeds and Survey in Ankara.

55) "Mahmud Çelebi veled-i Barak Beğ, serasker-i Amasya" (MAD 334, p. 22).

56) "Ahmed Çelebi veled-i Barak Beğ, defterdar-1 timar-i vilayet-i Rum" (MAD 334, p. 22). 
group of villages as mülk, probably from ancient times. Then his malikane-holding was turned into a timar, perhaps under Mehmed II, and he was registered in TT15 as a timariot with a large holding which also contained the divani revenues of the same villages. After the death of Mehmed II, his malikane-holding was returned to him and he soon turned it into a family waqf which, after his death, was held jointly by his sons, Mahmud and Yakubşah. Later Mahmud became the serasker of Amasya ${ }^{57}$ ) and held a timar in the 1490s; in the 1520s, he retained his timar, though not his post. ${ }^{58}$ ) Yakub and another brother, İsa, were also recorded as timariots in the $1520 \mathrm{~s},{ }^{59}$ ) while the fourth brother, Ahmed, who had not been mentioned in TT15, appeared in the 1490's as a timar defterdarl of the province of Rum and possibly held the same post in the 1520s. Meanwhile, Mahmud and Yakub kept their father's malikane-holding as vakf-l evlad; so did their sons up until 1576, the date of the compilation of the last tahrir defteri of the region.

Hüseyin Hüsameddin, the author of the multi-volumed Amasya Tarihi, mentions a "Barak Beğ," who held high-rank military and administrative posts in Amasya after 1437 and died in 1444, and his family which descended from the Şadgeldi family, the ruling family of the region before the Ottoman takeover. ${ }^{60}$ ) It is highly likely that the aforementioned Barak Beğ son of Mirza was from this family; if so, this might also explain the wealth and power of the family in the region. This account of the members of this family, over several generations under Ottoman rule, is a good illustration of how the Ottoman administration incorporated pre-Ottoman local nobility into its system. But it is also important in that the members of this family who were already a part of the Ottoman ruling class, the askeri, seem not to have been able to escape the reform of Mehmed II; their malikane holding, which they seem to have held as mülk from ancient times, appears in TT15 as being converted to mirî and was included in the timar that had perhaps already been granted to family members in return for their services to the state within the military and administrative apparatus of the empire. It should be pointed out that there were other cases recorded in TT15 where some timar-holders of local origin also held their malikane revenues as part of their timars following the reform of Mehmed II. Again, we see in the sixteenth century these revenues turned back to their previous status, either as

57) In TT15 of c. 1480 , the serasker of Amasya was a certain Ali Beg holding a timar of a large sum (TT15, p. 37).

58) “Timar-1 Yakub veled-i Barak Beğ" (TT95, p. 87); “Timar-1 Mahmud, birader-i Ahmed Beğ" (TT95, p. 91).

59) "Timar-1 İsa, birader-i Barak Ahmed Beğ" (TT95, p. 92).

60) Hüseyin Hüsameddin 1927, pp. 209, 211-12, 217. 
mülk, or vakf-ı evlad, or "mülk-i eşkünlü" and held by the descendants of the same families. ${ }^{61}$ )

From the picture presented above, what can be said about the process of Mehmed II's reform in the district of Amasya? It appears that the 46 'mülk timars' with the obligation of essküncü and the above mentioned timar-holders, who were originally of local nobility, were the only, though very limited, developments that can possibly be associated with the reform in the region. As explained earlier, in the case of the former, there was no abolishment whatsoever of the malikane revenues already held by freeholders as mülk or vakuf. The only gain to the central administration in imposing eşküncü on some mülk-holders was that it created an extra source of manpower for the army, without resorting to the state treasury. Only in the latter can one speak of an abrogation of certain freeholds, though in effect, even after conversion, these revenues were still kept by their previous owners, now under the status of timar-holder. Although this notion seems to have been limited only to certain influential families, it reveals yet another aspect of Mehmed II's reform, in an area where the malikane-divani system was in force.

All the malikane revenues recorded in TT15 along with the 'mülk timars' constituted only a small section of the mülk- and vaklf-holdings that existed in the district of Amasya. The vast majority of the freeholds of the region seem to have remained outside the reform of Mehmed II. This is apparent from the fact that the register compiled around 1520 records hundreds of mülk- and vaklfholdings which are not mentioned at all in TT15. Under the circumstances, it is not possible to ascertain whether these freeholds went through an intrusion by the state during the later stages of the reform, with their freehold status being later restored under Bayezid II. If that was the case, one should remember that the subsequent registers would have been expected to mention it directly or indirectly, as was the case for other parts of the empire. The sixteenth century registers of the Amasya region, however, give no mention of any such intrusion. What they reveal instead is the fact that a great majority of the malikane revenues recorded in TT15 as 'mevkufat' appear in these registers as parts of mülkand vaklf-holdings of various kinds, and that all 'mülk timars' except one were returned to their previous status of freehold without the obligation of eşküncü. ${ }^{62}$ ) As pointed out above, a limited number of freeholds which were converted into

61) Among these were, for instance, the sons of Sekban Temür, from the Pervane family of the Seljukids (see TT15, p. 40; TT387, pp. 357, 360; TT95, p. 87; TK26, pp. 104b-105a, $159 a-159 b, 160 a)$.

62) For the list of these mülk timars and their positions in the sixteenth century, see Özel 1993, Appendix II/A. 
mirî, but still held by their previous owners as timar during the reform years, would appear to gain their previous status as mülk or vaklf probably immediately after the death of the reformist Sultan, Mehmed II, in 1481.

\section{Conclusion}

From the analysis of the subject the following conclusions can be drawn:

The first point concerns the nature of the reform. It should be pointed out that the reform of Mehmed II was in fact 'fiscal' in character, and cannot be called 'land reform', as it is generally referred to in historiography. It simply did not involve any change in either ownership or use of land. The main target of the reform was the revenue derived from agricultural production and held by individuals as mülk or by institutions as vaklf. In this sense, the reform aimed at a change in the revenue-holding system in the empire. Whatever the theoretical debates over their status, all types of mülks and vakufs in the Ottoman Empire in effect concerned only the proprietory rights of the revenues, i.e. agricultural surplus in the form of tax or rent, not the land itself. As pointed out earlier, the land within the mirî system was owned by the state and cultivated by the peasantry largely within the çift-hane system of small peasant farms. Mülk- or vaklfholders did not own the land, and, therefore, had no right to alter its status. Nor did they have the right to change the basic relationships of the peasantry with the land in their holdings, which were determined at the outset by the state.

The second point relates to the extent of the reform. As reflected in the district of Amasya, where the malikane-divani type of revenue-holding system was in force, Mehmed II's reform seems to have been rather superficial; most of the mülk- and vakif-holdings converted to mirî or state property were still held by their previous (malikane-) holders after the conversion with simply a change in their status to "timariot", either ordinary or essküncülü. Therefore, as far as the information presented in TT15 is concerned, it is not possible to see in this region a radical attempt at abolishing or abrogating the mülk- and vaklf-holdings; instead, it appears to have been rather limited in scope and carefully applied, not aiming at severely undermining the economic resources of the local nobility. In its limited form, the reform did not seem to have brought any serious change even to the already existing revenue-holding system.

Here, a comparison may be made with the implementation of the reform in other parts of the empire. It is known from the research done on the subject that the reform had serious effects on the mülk- and vaklf-holdings which had initially been established on the basis of the previous Ottoman sultans' revenue grants, i.e. temliks, from the state lands. As pointed out earlier, this kind of grant was usually given to individuals, either high-ranking military men or the 
members of the imperial household, or sheikhs and dervishes who played important roles, particularly in the Ottoman settlement process in newly conquered territories. Such freeholds were largely concentrated in the western provinces of Anatolia and in the Balkan territories, and their numbers had increased rapidly even under Mehmed II himself. ${ }^{63}$ ) It is highly likely that the main target of Mehmed II's reform was these mülks and vakıfs; they after all did not have strong pre-Ottoman connections, thus not representing a deeply rooted local nobility, which was the case in the province of Rum. The superficiality of the reform in the district of Amasya may perhaps partly be accounted for by this, and the case of Amasya may well represent the overall situation in the whole province of Rum. Needless to say, however, this assumption needs further research into existing sources, which is beyond the scope of this study.

The third point is about the effect of the reform. As in all other parts of the empire, the changes brought about by the reform did not last long, and, immediately after the death of Mehmed II, the previous status of most of the freeholds was restored under Bayezid II. As for the political dimension of the reform, it is obvious that Mehmed II's reform was not limited to fiscal concerns; it seems that it was intended also to restrict the economic power of the local aristocracy, whose influence in political affairs was becoming apparent and manifested itself increasingly in the internal struggle for power throughout the fifteenth century. As reflected in chronicles such as Aşıkpaşazade's, widespread discontent arose among the various sectors directly targeted by the reform; these sectors were the ones who eventually won the victory. It would not be incorrect, therefore, to assume that the reform did not achieve its goals, either fiscal or political, thus showing the limits of the power of the Ottoman sultans themselves. It seems that no other Ottoman sultan after Mehmed II would ever attempt to exercise their power by trying to abolish hereditary rights of either the Anatolian malikane-holding class or mülk- and vakuf-holdings of any kinds in the empire on this scale. ${ }^{64}$ ) In this context, the claim that similar fiscal reforms were carried out to a lesser degree under Selim I and Suleiman the Magnificent in the sixteenth century should also be approached with caution and requires a serious re-examination.

Finally certain remarks on the historiography of the subject can be made. As is known, the beginning of the twentieth century witnessed large-scale land reforms in the Balkan countries, which had previously been part of the Ottoman

63) See particularly Cvetkova 1963; Beldiceanu 1965, p. 37; Moutafchieva 1988, pp. 132138. Compare Gökbilgin 1952.

64) Compare Barkan 1980a, p. 282. 
Empire. These were truly land reforms in that they involved distribution of land to the peasants. It is obvious that such a land reform was never attempted in the Ottoman Empire. It seems, however, that there is an anachronistic relationship between this twentieth-century experience and the mid-fifteenth centuryfiscal reform of Mehmed II, in that it was the historians of the earlier decades of the twentieth century who first referred to this reform; later, other historians mentioned at the beginning of this study, largely of Balkan origin, and applying orthodox Marxist terminology, furthered the studies on the subject in the 1960's. They used the terminology of their times, without taking into account the different nature of mülk- and vaklf-holdings in the fifteenth century Ottoman Empire, and referred to Mehmed II's attempt as a reform aimed at a radical change in land relations, therefore, called it 'land reform'. On the other hand the terminology of the Ottoman registry office seems to have further contributed to the confusion. Although these scholars were aware that the freeholds in general involved only the revenues, not the land, they, it seems, applied this terminology rather uncritically in their works.

To give an example which one often sees in historiography, terms such as 'mülk-land (or village)' or 'vakıf-land (or village)' in fact referred to a 'fiscal territory' on the basis of the status of the revenues which derived from a given piece of land, not at all to the territory itself. The importance of this distinction lies in the fact that, when the Ottoman sources referred to the conversion or abolishment of thousands of 'mülk-' or 'vaklf-villages' into mirî, as was the case in Mehmed II's reform, this terminology was borrowed by modern scholars and used in their works as such. The result is rather misleading: Mehmed II's reform abolished the mülk and vaklf-lands and turned them into mirî; here the land, not the revenue, becomes the main object of the reform, which of course was not the case at all.

Generally speaking, Ottomanists today still approach the reform of Mehmed II in these terms, thus causing serious confusion, if not complete misunderstanding among themselves. The present study at this point addresses the problem of the serious mismatch between the reform in question as a historical fact and the terminology employed by modern scholars to explain it. Therefore, what is suggested here is that a) modern scholars should appreciate the fact that Mehmed II's reform was in no way a land reform, it was simply a 'fiscal' reform which never involved land relations, b) that present historiography on the subject should be revised with this in mind, and finally, c) needless to say, both Ottoman official terminology and modern terminology should be approached and used with extreme care to avoid anachronism. 


\section{BIBLIOGRAPHY}

Arıkan, Zeki

1988 XV-XVI. Yüzyıllarda Hamit Sancăğ (İzmir: Ege Üniversitesi Edebiyat Fakültesi Yayınları).

Aşıkpaşaoğlu Ahmed Aşıkî

1949 Tevârih-i Âl-i Osman, In N. Atsız ed., Osmanlı Tarihleri (İstanbul: Türkiye Yayınevi).

Barkan, Ömer L.

1942 “Osmanlı İmparatorluğu'nda Bir İskan ve Kolonizasyon Metodu Olarak Vakıflar ve Temlikler. I. İstila Devirlerinin Kolonizatör Türk Dervişleri ve Zâviyeler." Vakıflar Dergisi 2: 279-386.

$1945 X V$-XVI. Yüzyıllarda Osmanlı Imparatorluğu'nda Zirâ̂ Ekonominin Hukuki ve Mali Esasları, 1. Kanunlar (İstanbul: İstanbul Üniversitesi Edebiyat Fakültesi Yayınları).

1980a “Türkiye'de Toprak Meselesinin Tarihi Esasları.” In Ömer L. Barkan, Türkiye' de Toprak Meselesi. Toplu Eserler 1 (İstanbul: Gözlem Yayınları), pp. 125-149.

1980b “Türk-İslam Toprak Hukuku Tatbikatının Osmanlı İmparatorluğu’nda Aldığı Şekiller: Mülk Topraklar ve Sultanların Temlik Hakkı.” In Türkiye’de Toprak Meselesi, pp. 231-247.

1980c “Türk-İslam Toprak Hukuku Tatbikatının Osmanlı İmparatorluğu'nda Aldığı Şekiller: İmparatorluk Devrinde Toprak Mülk ve Vakıflarının Hususiyeti.” In Türkiye' de Toprak Meselesi, pp. 249-280.

1980d “Türk-İslam Toprak Hukuku Tatbikatının Osmanlı İmparatorluğu'nda Aldığ Şekiller: Malikâne-Divânî Sistemi." In Türkiye’de Toprak Meselesi, pp. 151208.

1980e “Türk-İslam Toprak Hukuku Tatbikatının Osmanlı İmparatorluğu'nda Aldığı Şekiller: Şer'i Miras Hukuku ve Evlatlık Vakıflar.” In Türkiye’ de Toprak Meselesi, pp. 209-230.

$1980 f$ “Osmanlı Devrinin ‘Eşkincülü Mülkler'i veya 'Mülk Timarlar’ı Hakkında Notlar.” In Türkiye’ de Toprak Meselesi, pp. 897-904.

Beldiceanu, Nicoara

1965 "Recherches sur la réforme foncière de Mehmed II." Acta Historica 4: 27-39.

1980 Le Tımar dans l'état ottoman (début xlve-début xvll siecle) (Wiesbaden: Otto Harrassowitz).

Beldiceanu-Steinherr, Irene

1976 "Fiscalité et formes de possession de la terre arable dans l'Anatolie pré-ottomane." Journal of the Economic and Social History of the Orient 19: 241-277.

Cvetkova, Bistra "ra

1963 "Sur certaines reformes du régime foncièr au temps de Mehmed II." Journal of the Economic and Social History of the Orient 6: 104-120.

Esterâbâdi, Aziz bin Ardeşir-i

1990 Bezm ü Rezm, trans., Mürsel Öztürk (Ankara: Kültür Bakanlığ1 Yayınları).

Gökbilgin, M. Tayyip

$1952 X V$ ve XVI. Asırlarda Edirne ve Paşa Livası. Vakıflar-Mülkler-Mukatalar (İstanbul: İstanbul Üniversitesi Edebiyat Fakültesi Yayınevi).

Hüseyin Hüsameddin

1927 Amasya Tarihi (İstanbul: Hikmet Matbaası), vol. 3.

İnalcık, Halil

1947 "Bursa Şer'iye Sicillerinde Fatih Sultan Mehmed'in Fermanları." Belleten 11.44: 693-708. 
1957 "Mehmed II." İslam Ansiklopedisi, 7: 506-535.

1970 "The Rise of the Ottoman Empire.", In P. M. Holt, Ann K. S. Lambton, and B. Lewis eds., The Cambridge History of Islam (Cambridge: Cambridge University Press), vol. 1, part A, pp. 295-323.

1973 The Ottoman Empire: The Classical Age 1300-1600, trans., N. Itzkovitz and C. Imber (London: Weidenfeld and Nicholson).

1975 "Kanunname." Encyclopaedia of Islam² 4: 562-66.

1991 "Mehemmed II." Encyclopaedia of Islam² 6: 978-981.

1992 "İslam Arazi ve Vergi Sisteminin Teşekkülü ve Osmanlı Devrindeki Şekillerle Mukayesesi.” In Halil İnalcık, Osmanlı Imparatorluğu, Toplum ve Ekonomi (İstanbul: Eren Yayınlar1), pp. 15-30.

1993 "Village, Peasant and Empire." In Halil İnalc1k, The Middle East and the Balkans under the Ottoman Empire. Essays on Economy and Society (Bloomington: Indiana University Turkish Studies and Turkish Ministry of Culture Joint Series), pp. 137-160.

1994 "The Ottoman State: Economy and Society, 1300-1600." In Halil İnalcık and Donald Quataert eds., An Economic and Social History of the Ottoman Empire, 1300-1914 (Cambridge: Cambridge University Press), pp. 9-409.

Kunt, İ. Metin

1988 "Siyasal Tarih, 1300-1600.” In Sina Akşin ed., Türkiye Tarihi. Osmanlı Devleti, 1300-1600 (İstanbul: Cem Yayınları), vol. 2, pp. 15-144.

Moutafchieva, Vera

1988 Agrarian Relations in the Ottoman Empire in the 15th and 16th Centuries (New York: Columbia University Press).

\section{Murphey, Rhoads}

1995-96 "The Conceptual and Pragmatic Uses of the 'Summary' (Idjmal) Register in Sixteenth-Century Ottoman Administration." Archivum Ottomanicum 14: 111131.

Öz, Mehmet

1994 "Tahrir Defterlerine Göre Vezirköprü Yöresinde Malikane-Divani Sistemi." Vakıflar Dergisi 23: 229-241.

Özel, Oktay

1993 "Changes in Settlement Patterns, Population and Society in Rural Anatolia: A Case Study of Amasya (1576-1642)." (Ph.D. diss., Victoria University, Manchester).

Sertoğlu, Mithat

1970 "Osmanlı İmparatorluğu'nda XV. ve XVI. Yüzyıllarda Girişilen Toprak Reformları ve Sonuçları.” Belgelerle Türk Tarihi Dergisi 35: 68-71.

Turan, Osman

1970 "Anatolia in the period of the Seljuks and the Beyliks." In P. M. Holt, A. K. S. Lambton and B. Lewis eds., The Cambridge History of Islam (Cambridge: Cambridge University Press), vol. 1, part A, pp. 248-253.

Tursun Bey

1977 Tarih-i Ebü'l Feth, ed. Mertol Tulum (İstanbul: İstanbul Fetih Cemiyeti Vatin, Nicolas Yayınları).

1989 "L'ascension des Ottomans (1451-1512)." In Robert Mantran ed., Histoire de l'empire ottoman (Poitiers: Fayard), pp. 81-116.

Venzke, Margaret L.

1986 "Aleppo's Malikane-Divani System." Journal of the American Oriental Society 106.3: 451-469. 